\title{
Microscopic and Molecular Detection of Entamoeba histolytica in Selected Public Primary School Pupils of Bwari Area Council, F.C.T Abuja, Nigeria
}

\author{
F. R. Okusaga, R. J. Ombugadu, A. B. Yako, and G. A. Amuga
}

\section{ABSTRACT}

This study evaluated the prevalence of Entamoeba histolytica using microscopic detection and confirmed by DNA analysis using polymerase chain reaction (PCR) technique by taking samples of some public primary school pupils within Bwari Area Council of Abuja, Nigeria. Microscopic and polymerase chain reaction-restriction fragment length polymorphism analysis targeting only a small portion $(228 \mathrm{bp})$ of the adh112 gene. Results showed that out of three hundred and twenty (320) stool sample screened, twenty six $26(8.1 \%)$ were found to be positive of the parasite. The prevalence was high among pupils in school 4 with $7(11.2 \%)$ follow by school 5 with $(11.1 \%)$, school 3 with 5(8.3\%), school 1 with $5(7.3 \%)$ and the lowest school 2 with $(2.9 \%) P<0.05$. The prevalence was high among male with $18(13.2 \%)$ than the female $P<0.05$. The prevalent was high among age 4-9 had more $E$. histolytica than other age group with $16(12.8 \%) P<0.05$. The prevalence of $E$. histolytica was high among those that use Open space system toilet with $11(14.4 \%)$ than the other risk factors examined $P<0.05$. The polymerase chain reaction-restriction fragment length polymorphism showed that the entire twenty six parasite were $E$. histolytica as given on the Agarose gel electrophoresis with adh112 gene band of $228 \mathrm{bp}$. The sources of contracting amoebiasis include drinking of contaminated water, poor sanitation in living quarters, lack of or improper use of toilets, contact with flies and items contaminated by flies, among other hygiene related issues.

Keywords: Entamoeba histolytica, hygiene, prevalence, pupils.
Published Online: June 08, 2021

ISSN: $2684-5199$

DOI: $10.24018 /$ ejbio. 2021.2 .3 .196

\section{F. R. Okusaga*}

Department of Zoology, Nasarawa State University, PMB 1022, Keffi, Nigeria.

(e-mail: patiencesunday213@gmail.com) R. J. Ombugadu

Department of Zoology, Nasarawa State University, PMB 1022, Keffi, Nigeria.

(e-mail: ruthombugadu $@$ gmail.com)

A. B. Yako

Department of Zoology, Nasarawa State University, PMB 1022, Keffi, Nigeria.

(e-mail: 66yako@gmail.com)

G. A. Amuga

Department of Zoology, Nasarawa State University, PMB 1022, Keffi, Nigeria.

(e-mail: kamuga2@nsuk.edu.ng)

*Corresponding Author

\section{INTRODUCTION}

The organism "Entamoeba histolytica" is an anaerobic protozoan parasite that is cosmopolitan and upon infection of a human host, can cause human morbidity which can be compared to other infectious disease conditions like Malaria and Schistosomiasis [1]. The process of its infection is known as ameobiasis and usually affect the intestines. Globally, it has an estimated prevalence rate of 500 million infections, manifesting the disease symptoms and 40,000 to 110,000 deaths on annual basis [2]. It is a serious health challenge, especially in the developing countries of the world such as the sub-Saharan Africa. Although the magnitude of the infection varies from country to country on the basis of socioeconomic and geographical placement, sanitation and population density [3]. It is usually endemic in socio-economically backward communities, a characteristic of the tropical and subtropical areas. Lack of good environmental sanitation, socio-economically deprived communities, demographic factors, and poor hygiene are some of the prominent factors that facilitate the spread and distribution of this intestinal parasite among people [4]. Its transmission is often positively correlated with contaminated food, water, and finger-sucking habit. As a result, children are not mostly expected to be the ones coming down with amoebiasis. In the developed countries such as the US and UK, amoebiasis tends to be found mostly in aged people and among men who are homosexuals and in institutions. But in tropical regions, the epidemiology of the disease is mostly found among the population especially in patients attending health care facilities with cases of diarrhea. Clinical features of amoebiasis ranges from asymptomatic colonization, amoebic dysentery and invasive extraintestinal amoebiasis which is shown predominantly in the form of liver abscess [5]. About $10 \%$ of the world's population infected by $E$. histolytica usually develop the invasive form of the disease. Manifested symptoms may range from mild diarrhea, dysentery with blood and mucus in stools of infected individuals. Severe amoebic infections occur in two major forms: as either invasion of the intestinal lining causing amoebic dysentery or amoebic colitis. Ones the parasite finds its way into the bloodstream, it can spread through the body, most frequently ending up in the liver where it causes amoebic liver abscess. This does not preclude the fact that liver abscesses can occur without previous development of amoebic dysentery.

In asymptomatic cases, the infected individual is still a carrier and having the potential to transmit the parasite to others through poor hygienic practices and behaviours. The symptoms at onset can be similar to bacillary dysentery [6]. 
There is a paucity of information concerning the prevalence of $E$. histolytica using microscopy and adhesion detection methods in Nigeria. This study was therefore conducted to evaluate molecular detection of E. histolytica among selected primary schools' pupils in Bwari Area council, FCT Abuja, Nigeria.

\section{MAtERIALS AND METHODS}

\section{A. Study Area}

This research was conducted in Dutse Alhaji, Bwari Area Council, Abuja. Bwari lies within latitude $9^{\circ} 4^{\prime} \mathrm{E}$ and at latitude $7^{\circ} 29^{\prime} \mathrm{N}$ at the equator and $850 \mathrm{~m}$ above the sea level. Raining season in the area is usually between April and October with an average rainfall of $4.2 \mathrm{~mm}$ in April to 8.0 $\mathrm{mm}$ in October, daytime temperatures reach $28^{\circ} \mathrm{C}\left(82.4^{\circ} \mathrm{F}\right)$ to $30{ }^{\circ} \mathrm{C}\left(86.0{ }^{\circ} \mathrm{F}\right)$ and nighttime lows hover around $22{ }^{\circ} \mathrm{C}$ $\left(71.6{ }^{\circ} \mathrm{F}\right)$ to $23{ }^{\circ} \mathrm{C}\left(73.4{ }^{\circ} \mathrm{F}\right)$. Major occupations of the ingenuous people are farming. Bwari Area Council is approximately $32 \mathrm{~km}$ from the Federal Capital Territory (FCT) Abuja [7].

\section{B. Study Population}

Bwari Area Council has a total of nineteen (19) primary schools and five (5) primary schools were selected for this study, three hundred and twenty 320 primary schools' pupils were covered in the study.

\section{Criteria of Inclusion}

Pupils aged 4-14 years old were included in the study irrespective of their classes. These are the age group mostly at the risk of infection with intestinal parasites including $E$. histolityca due to their ignorant of good hygiene practices.

\section{Research Design}

The design of the research involved a cross-sectional study that captured the population of age between 4-14 years old across Bwari Area Council of Abuja, Nigeria. A cluster random sampling according to [8] was used to collect samples of stool from the school pupils.

\section{E. Sampling techniques and Sample size determination}

Bwari Area Council of the F.C.T, Abuja has a total of nineteen (19) primary schools. A cluster random sampling technique was adopted to sample the schools. Five (5) primary schools were eventually selected randomly. Also, pupils aged between 4 and 14 years old from each sampling school were randomly picked until the calculated sample size was determined. The sample size was determined by the method of [9] for calculating sample size.

Thus:

$$
\mathrm{n}=\mathrm{Z}^{2} \mathrm{pqD} / \mathrm{d}^{2}
$$

where

$\mathrm{n}=$ Sample size where population $<10,000$ (zone A has approximately number of pupils aged 4-14).

$\mathrm{Z}=$ Standard normal deviate which will corresponds to $95 \%$ confidence interval.

$\mathrm{P}=$ Proportion of the target population estimated to have a characteristic of the infection (this information will be obtained from the medical records at the zone Hospital).

$$
\mathrm{q}=1-\mathrm{p}
$$

$\mathrm{d}=$ Degree of accuracy desired for the study $=0.05$.

$\mathrm{D}=$ Design effect $=1$.

Therefore:

$$
\begin{array}{ll}
\mathrm{n}=? & \mathrm{n}=\underline{1.96^{2} \times 0.296 \times 0.704} \\
\mathrm{Z}=1.96 & 0.05^{2} \\
\mathrm{p}=0.296 & \mathrm{n}=\underline{3.84 \times 0.208384} \\
\mathrm{q}=1-\mathrm{p}(1-0.296) & 0.0025 \\
\mathrm{q}=0.704 & \mathrm{n}=\underline{0.80019456} \\
\mathrm{~d}=0.05 & 0.0025 \\
& \mathrm{n}=320.1 \\
& \mathrm{n}=320
\end{array}
$$

\section{F. Ethical Permission and Administrative Clearance}

Ethical permission was received from Federal Ministry of Health, Department of Primary Health Care, Bwari Area Council Abuja.

\section{G. Administration of Research Questionnaire}

Structured questionnaire was administered to the parents/guardians of the three hundred and twenty (320) pupils that were involved into the study. Respondents who could not read or write in English Language were interviewed in local language by the researcher.

The questionnaire was designed to provide information such as age, gender, occupation of parent's, educational background of parents and risk factors such as sucking habit.

\section{H. Sample Collection}

About $2.0 \mathrm{~g}$ of stool sample was collected from each of the three hundred and twenty (320) participating pupils. A clean dry sample bottles was given to each pupil for their stool sample. 2-3 drops of formalin were added to each sample and transported to the Zoology Laboratory for Laboratory Analysis. The positive samples were transported in ice packs to DNA laboratory limited Kaduna, kaduna state, Nigeria for molecular analysis. Formal - Ether Concentration Technique was used to process the stool as described by [10].

Procedure: A small sample (2.0 g) of stool was emulsified by treating with $5 \%$ of normal saline and was strain through the layers of Gauze in a funnel in a centrifuge tube until $7 \mathrm{ml}$ was obtained, then $3 \mathrm{ml}$ of ether was added to make $10 \mathrm{ml}$. The sample was centrifuge at $500 \mathrm{rpm}$ (Revolution per minute) for 2 minutes. The tube was removed, and the supernatant was discarded. A drop of the residue was transferred to a clean slide and cover slip was used to cover the slide. The slide was placed on the microscope stage and examine the residue for trophozoites and cyst using $\times 10$ and $\times 40$ objectives. The positive samples were stored for further analysis.

\section{Molecular Detection}

For the molecular detection, the Zymo spin IIC column ( $E$. histolytica II kit) (Zymo Research Corp) was used to detect DNA from the positive stool samples according to the manufacturer's instructions as described by [11]. 


\section{J. Statistical Analysis}

The data gathered was analyzed the level of significance of the prevalence of E. histolytica infections among the school children with the studied risk factors by using IBM SPSS version 23.0. Values obtained were considered significant at $\mathrm{P} \leq 0.05$.

\section{RESULTS AND DISCUSSION}

This study determined the prevalence of E. histolytica infection in primary school pupils around Bwari Area Council of the Federal Capital Terrirory, Abuja, Nigeria. The results showed that. of the 320 samples collected, $26(8.1 \%)$ were infected with Entamoeba histolytica which is lower than study reported by [12] who reported prevalence of $42.62 \%$ of $E$. histolytica infection among pre-school children Zaria shows that the disease is endemic in study area and is in disagreement with study reported by Ozlem and Hakan [17]. But is in agreement with findings reported in other countries like 2.6\% from Makkah, Saudi Arabia [12]. The relatively prevalence of $E$. histolytica infection reported in this study might relates to poverty, lack of proper drainage system, indiscriminate disposal of sewage, lack of potable water, indiscriminate defecation, ignorance and low standard of personal hygiene in the study area and among school children. In respect to selected primary school the prevalence was high among pupils in school 4 with $7(11.2 \%$ ) follow by school 5 with $(11.1 \%)$, school 3 with $5(8.3 \%)$, school 1 with $5(7.3 \%)$ and the lowest school 2 with $(2(2.9)$ and in respect gender the prevalence was high among in males with 18 $(13.7 \%)$ and $8(4.2 \%)$ in female as given in Table I. This is in agreement with the work of [14], [4] in Abia State which recorded $18.7 \%$ among male and $13.3 \%$ among females. [13] in Lafia city reported higher prevalence in males $(27.7 \%)$ than females $(24.3 \%)$. The significantly high prevalence of infection observed among male children may be attributed to the fact that they are more adventurous than their female counterparts and have a greater chance of indulging in outdoor activities [14], [15]. It could also be that male engages more in activities that predisposes them to the infections such as playing football, farming, fishing, hunting. These activities necessitated more contact and exposure to the infections. On the other hand, female children are more preoccupied with household works which limit their level of exposure to the possible sources of infection [16].

The prevalence was high in age group of 4-9 with 16 $(12.8 \%)$ and age group of $10-14$ with $10(5.0 \%)$ as shown in
Table II. The prevalence of E. histolytica infection in relation to the type of toilet facility used in their homes is presented in Table III. Of which the children from homes where Open space system is used had the highest prevalence of $11(14.4 \%)$ followed by those who use pit latrine with $9(8.7 \%)$ and those children that septic tank system are used in their homes with $6(4.2 \%)$. The prevalence of E. histolytica infection in relation to the source of drinking water as shown in Table IV. This could be because of the fact that children within this age group are always playing on the sand with no care. They tend to be ignorant to the principle of cleanliness and personal hygiene. At of the 320 respondents, the highest prevalence was finding among those that drink Stream/River water with $6(17.1 \%)$ followed by those that who drink well/Borehole water with $18(8.4 \%)$ and the least are those that drink tap water with $2(2.7 \%)$, respectively. The prevalence of $E$. histolytica infection among children who suck and do not suck their finger, the highest prevalence was observed among those who suck their finger with $17(16.0 \%)$ while those that do not suck their finger had $9(4.2 \%)$ respectively as shown in Table III The study revealed a high prevalence rate of among children between age group 4-9 years than those aged $10-14$ years respectively. This study is in agreement with studies of [1], [4], [6], [17].

In this study source of drinking water maybe a factor responsible for infection by $E$. histolytica. Many starlight communities in the study area depends on well/boreholes and stream water for drinking and other domestic uses; these sources of water are usually left uncovered and are subject to contamination with cysts of E. histolytica, which are the infective stage, from various types of wastes including human and animal faeces.

Plate 2 shows the molecular DNA of polymerase chain reaction-restriction fragment length polymorphism gene adh 112 band of $228 \mathrm{bp}$ of the E. histolytica from the stool of the pupils from the study area of the 26 positive stool samples.

TABLE I: Microscopic DeteCtion of E. HistolytiCA AMONG SELECTED PRIMARY SCHOOL PUPILS IN BWARI AREA COUNCIL USING DIRECT SMEAR

\begin{tabular}{cccc}
\multicolumn{4}{c}{ METHODS IN THE YEAR 2019 } \\
\hline \multirow{2}{*}{ School } & $\begin{array}{c}\text { Total } \\
\text { sample }\end{array}$ & $\begin{array}{c}\text { No. of Positive } \\
(\%)\end{array}$ & $\begin{array}{c}\text { No. of Negative } \\
(\%) X^{2}\end{array}$ \\
\hline 1 & 68 & $5(7.3)$ & $63(92.6) 0.00$ \\
2 & 67 & $2(2.9)$ & $65(97.00) 0.00$ \\
3 & 60 & $5(8.3)$ & $55(91.7) 0.00$ \\
4 & 62 & $7(11.2)$ & $55(88.7) 0.00$ \\
5 & 63 & $7(11.1)$ & $56(62.9) 0.00$ \\
\hline Total & 320 & $26(8.1)$ & $294(91.9)$ \\
\hline
\end{tabular}

TABLE II: The Prevalence of E. Histolytica in SOME SElEcted Primary SCHOOL PUPILS AROUND BWARI AREA COUNCIL AND IN RELATION TO GENDER IN THE YEAR 2019

\begin{tabular}{|c|c|c|c|c|c|c|c|c|c|}
\hline school & $\begin{array}{c}\text { No of } \\
\text { sample } \\
\text { Female }\end{array}$ & $\begin{array}{c}\text { No of } \\
\text { sample } \\
\text { Male }\end{array}$ & $\begin{array}{c}\text { Total } \\
\text { samples }\end{array}$ & $\begin{array}{c}\text { Female } \\
(+) \%\end{array}$ & $\begin{array}{l}\text { Male } \\
(+) \%\end{array}$ & $\begin{array}{c}\text { Total positive } \\
(\%)\end{array}$ & $\begin{array}{c}\text { Total negative } \\
(\%)\end{array}$ & $\begin{array}{l}X^{2} \\
(\mathrm{~F})\end{array}$ & $\begin{array}{c}X^{2} \\
(\mathrm{M})\end{array}$ \\
\hline 1 & 37 & 31 & 68 & $2(5.4)$ & $3(9.6)$ & $5(7.3)$ & $63(92.6)$ & 0.00 & 0.00 \\
\hline 2 & 39 & 28 & 67 & $1(2.5)$ & $1(3.5)$ & $2(2.9)$ & $65(97.00)$ & 0.00 & 0.00 \\
\hline 3 & 34 & 26 & 60 & $0(00)$ & $5(19.2)$ & $5(8.3)$ & $55(91.7)$ & 0.00 & 0.00 \\
\hline 4 & 41 & 21 & 62 & $3(7.1)$ & $4(19.0)$ & $7(11.2)$ & $55(88.7)$ & 0.00 & 0.00 \\
\hline 5 & 38 & 25 & 63 & $2(5.2)$ & $5(20.0)$ & $7(11.1)$ & $56(62.9)$ & 0.00 & 0.00 \\
\hline Total & 189 & 131 & 320 & $8(4.2)$ & $18(13.7)$ & $26(8.1)$ & 294(91.9) & & \\
\hline
\end{tabular}


TABLE III: The PREVAlEnce of E. hISTOLYTICA IN Some SElected PRIMARY SCHOOL PUPILS IN BWARI AREA COUNCIL IN RELATION TO AGE

\begin{tabular}{cccc}
\multicolumn{4}{c}{ IN THE YEAR 2019 } \\
\hline \multirow{2}{*}{ Ages } & $\begin{array}{c}\text { No. of } \\
\text { sample }\end{array}$ & $\begin{array}{c}\text { No. of } \\
\text { positive }(\%)\end{array}$ & $\begin{array}{c}\text { No. of negative (\%) } \\
X^{2}\end{array}$ \\
\hline $4-9$ & 124 & $16(12.9)$ & $108(87.1) 0.00$ \\
$10-14$ & 196 & $10(5.1)$ & $186(94.9) 0.00$ \\
Total & 320 & $26(8.1)$ & $294(91.9)$ \\
\hline
\end{tabular}

TABLE IV: THE PREVALENCE OF E. Histolytica INFECTION WITH RESPECT TO RISK FACTORS AMONG THE STUDY POPULATION IN BWARI

\begin{tabular}{cccc} 
& AREA COUNCIL IN THE YEAR 2019 \\
\hline Risk Factors & $\begin{array}{c}\text { No. of } \\
\text { sample }\end{array}$ & $\begin{array}{c}\text { No. of } \\
\text { positive }(\%)\end{array}$ & $\begin{array}{c}\text { No. of negative } \\
(\%) X^{2}\end{array}$ \\
\hline Type of toilet & & & $94(91.3) 0.001$ \\
Pit & 103 & $9(8.7)$ & $65(85.5) 0.003$ \\
Open space & 76 & $11(14.4)$ & $135(95.7) 0.001$ \\
septic tank system & 141 & $6(4.2)$ & \\
Finger sucking & & & $89(84.0) 0.002$ \\
habits & 106 & $17(16.0)$ & $205(95.8) 0.004$ \\
Yes & 214 & $9(4.2)$ & \\
No & & & $70(97.2) 0.001$ \\
Drinking water & & $2(2.7)$ & $29(82.6) 0.01$ \\
source & 72 & $18(8.4)$ & \\
Tap water & 213 & $6(17.1)$ &
\end{tabular}

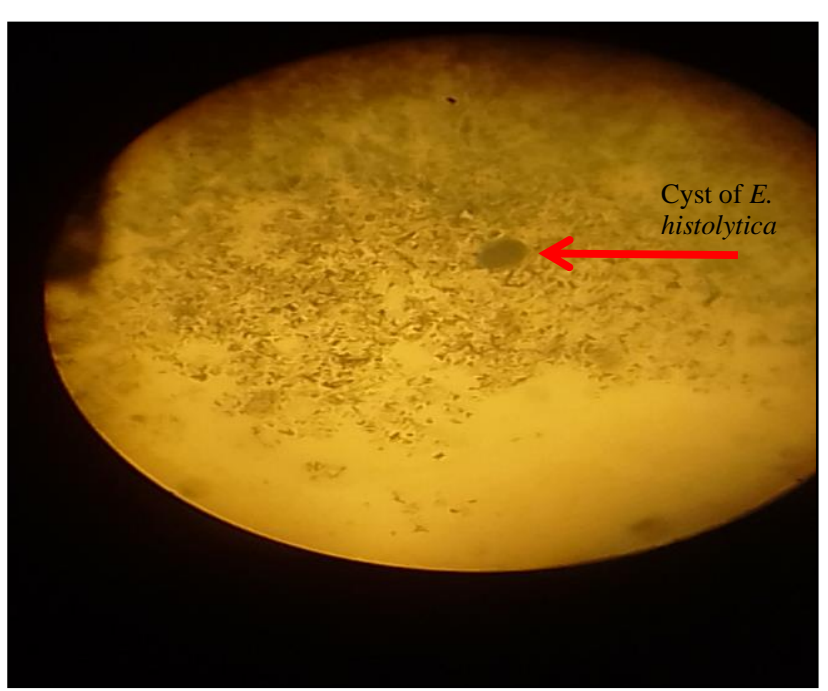

Plate 1. As observed under the light microscope in this research with magnification $\times 40$.

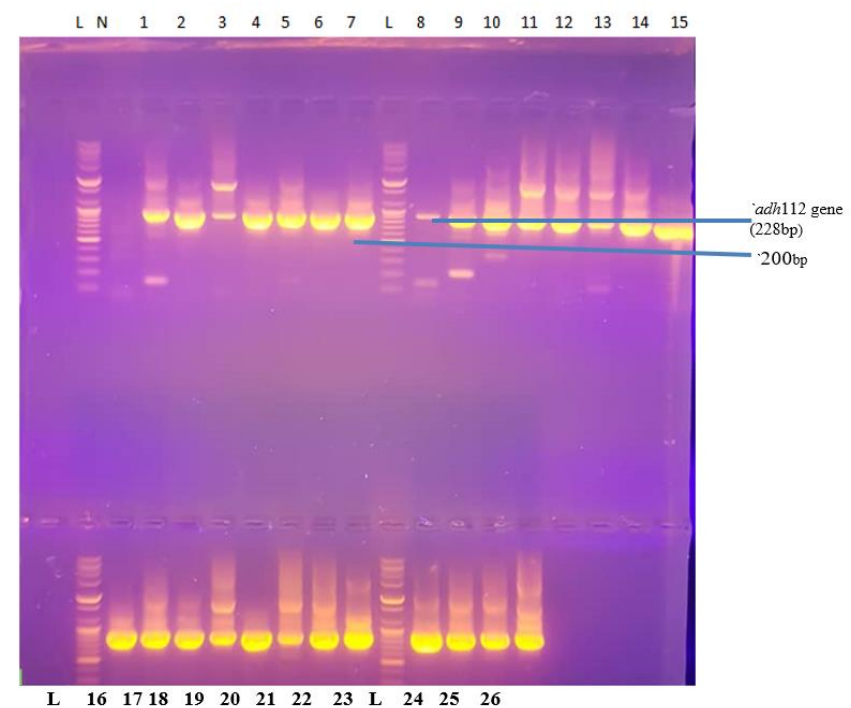

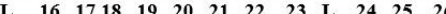

Plate 2. The agarose gel electrophoresis of the polymerase chain reactionrestriction fragment length polymorphism (PCR-RFLP). Lanes 1-26 represent the DNA bands of adh112 gene (228bp). While Lane N represents the negative control; lane L represents the 1000bp molecular ladder.

\section{CONCLUSION}

Primary school pupils in the Bwari area council of the F.C.T Abuja irrespective of the pupils' sexes and ages although the infection rate was observed to be higher in males than females and in older school aged pupils than their younger counterparts. This may be due to poor hygiene amongst the older aged school children.

\section{ACKNOWLEDGMENT}

We would like to acknowledge Engr. O. A. Afolayan for the inspiration and financial support during the research.

\section{REFERENCES}

[1] Reuben, C. R., Katsa, M., Hassan, S. C. (2013). Prevalence of intestinal amoebiasis in school age children in Lafia, Nassarawa State, Nigeria. International Research Journal of Biological Sciences, 2(7): 42-45.

[2] Simon-Oke, I. A. and Ogunleye, E. (2015). Prevalence of Entamoeba histolytica among primary school children in Akure, Ondo State, Nigeria. Journal of Public Health and Epidemiology, 7(11): 346351.

[3] Nader, P., Mahnaz, N., Ali, H., Mansour, S. and Hosinali, Y. (2015). Frequency of Entamoeba histolytica and Entamoeba dispar prevalence among patients with gastrointestinal complaints in Chelgerd city, Southwest of Iran. Journal of Medical Science Research. 16(11): 14361440 .

[4] Amaechi, E. C., Ohaeri, C. C., Ukpai, O. M., Nwachukwu, P. C. and Ukoha, U.K. (2014). Prevalence of Entamoeba histolytica among primary school children in Ukwa West Local Government Area, Abia State, South East, Nigeria. The Bioscientist, 2(1): 1-7.

[5] Fotedar, R., Stark, D., Beebe, N., Marriott, D., Ellis, J.and Harkness, J. (2007). Laboratory diagnostic techniques for Entamoeba species. Clinical Microbiology Revision. 20(3): 32-40.

[6] Gimba, U. N., Azare, A. B. and Alao, A. O. (2014). Evaluation of Entamoeba histolytica transmission rates amongst primary school children in five selected communities in Gwagwalada Area council, FCT-Abuja, Nigeria. Journal of Biology, Agriculture and Healthcare, 4(27): 22-30.

[7] Federal Capital Development Authority (2018). Planning Research Corporation geographical layout.

[8] Kombo, D. and Tromp, D. (2016). Proposal and thesis writing, an introduction. Paulines Publications, Nairobi, Kenya, 2: 70-79, 130-133.

[9] Wayne, W. (2010). Biostatistics; Basic concepts and methodology for the Health Sciences,9th Edition. Willey and Sons, Asia. Pp. 192-196.

[10] Cheesbrough M. (2009). District laboratory practice in tropical countries. Part 1.6th Ed. Cambridge University Press. 350.

[11] Saeed, A. A and Manal, B. J (2007). Diagnosis and differentiation of Entamoeba infection in Makkah Al Mukarramah using microscopy and stool antigen detection kits. World Journal of Medical Science. 2(1): 15-20.

[12] Ngobeni, R., Abhyankar, M. M., and Jiang, N. M. (2017). Entamoeba histolytica-encoded homolog of macrophage migration inhibitory factor contributes to mucosal inflammation during amebic colitis. Journal of Infectionus Diseases; 215: 1294 -302.

[13] Mortimer, L., Moreau, F., Cornick, S., and Chadee, K. (2014). Gallectin-dependent contact activates the inflammasome by invasive Entamoeba histolytica. Mucosal Immunol. 7, 829-841.

[14] Inabo, H., Galadima, M., Ogbadu, L. J and Okuofu, C. A (2000). Prevalence of Entamoeba histolytica and Giardia lambliain primary school pupils in five rural villages around Kaduna and Zaria, Nigeria. Nigerian Journal of Parasitology. 21: 61-67.

[15] Aza, N., Ashley S and Albert, J. (2003). Parasitic Infections in human communities living on the fringes of the Crocker range park, Sabah, Malaysia. ASEAN Revision of Biodiversity and Environmental Conservation (ARBEC). 3: 100-110.

[16] Aksoy, U., Akisu, C., Bayram-Delibas, S., Ozkoc, S and Sahin, S, (2007). Demographic status and prevalence of intestinal parasitic infections in school children in Izmir, Turkey. Turkish Journal of Paediatrics. 49: 278-282.

[17] Ozlem, O and Hakan, S. (2005). The contamination of various fruits and vegetables with Eterobius vemicularis, Ascaris eggs, E. histolytica cysts and Giardia cysts. Science Direct, 16(6): 557-560. 